\title{
地層の厚さとその分布について
}

\author{
水谷伸治郎 ${ }^{1 *}$
}

\section{Bed-thickness and its frequency distribution}

\begin{abstract}
Shinjiro Mizutani ${ }^{1 *}$
The bed-thickness of sedimentary beds and its frequency distribution in a geological body have been treated to show a lognormal distribution. In this paper it is discussed on a basis of a model presented by a great Russian mathematician, Prof. Kolmogorov, A.N. who said that a sedimentary bed has a thickness of so-and-so cm, but in some cases, it has a negative thickness. Actually, the presence of a washed -out phenomena will erode the pre-existing sedimentary layer, and sometimes the pre-existing will completely disappear. For such a washed-out bed, Kolmogorov described that it has a negative thickness. In this paper, an example for the Neogene Kakegawa Formation and its bed-thickness is presented, and additionally the bed-thickness of varved diatomite in the Hiruzenbara Formation of Okayama Prefecture is noted as an example of rather accumulative type of sedimentation.
\end{abstract}

Key words : bed-thickness, Kolmogorov, distribution, wash -out

\section{はじめに}

先日, 送られてきた『堆積学研究』(Journal of the Sedimetological Society of Japan, vol. 74, no. 2, 2015）の表紙には, みごとな縞状堆積物の写真が載せられている.さらに, こ の表紙の説明として, Cover Story には, 石原与四郎・佐々 木 華 (福岡大学) による英文 (ならびに, 和文) の記述が ある (Ishihara and Sasaki, 2015)。私は，この岡山県蒜山原 高原の湖成縞状珪藻土（中部更新統）の分布地域を訪れた ことはないが, しかし，ここに示されている厚さ 1〜2 mm の濃淡の葉理のセットからなる年縞の見事さには驚いた.

どうして，このような縞に見える模様できるのか, そし て, それらの縞模様が如何なる環境を反映しているのか, という極めて素朴な疑問は, 古くからあった.

1943 年, 名著“Archean sedimentation” (Pettijohn, 1943) を 書き上げた Pettijohn は，ついで，Pettijohn（1949）をまと

受付: 2016 年 2 月 9 日 受理 : 2016 年 3 月 28 日

1 广465-0084 名古屋市名東区代万町 2-21

2-21, Daiman-cho, Meito-ku, Nagoya City, 465-0086, Japan

* Corresponding author: jiro@sd.starcat.ne.jp
め, 地層の厚さについての問題を指摘した. そして, 新し い時代のものについてだけではなく, 古い基盤岩類に見ら れる縞状片岩についても, その厚さの分布について, 議論 された (Simonen, 1953; Simonen and Kouvo, 1951). 堆積地 質学者の間では, Bokman (1957)の指摘などに注目が集まっ た。

これらの例が示すように，地質学者の間では，地層の厚 さに関しては, 経験的に, その厚さを対数でとれば, 全体 として山の形をし, 左右に裾野をひく形を示すので, いわ ゆる「対数正規分布 (lognormal distribution)」をすると信じ られてきた。

私は, かつて, 服部 勇氏と二人で, この問題について 議論したことがあった（Mizutani and Hattori, 1972; 水谷・服 部, 1973).また, 最近, Drummond (1999) を読んで, まだ, 似たような議論が続いていることを知って, 再び, 筆を執っ て, 紹介したことがある（水谷, 2000)。ここでは, それら を思い出して, 極めて, 根本的な問題, “いかにして層理面 ができるのであろうか?”という疑問を, ソ連の大数学者, Kolmogorovのモデルを紹介しながら，考察する.

最初に, あまり我々には, 馴染みのないKolmogorov, A.N. 
について，簡単に記すことにする。たまたま，私の友人に， 名古屋大学理学部の数学科出身の櫃田倍之先生（元 : 熊本 大学理学部長) を紹介されたことがあった。 その時, 私は, 櫃田先生に, 彼 (Kolmogorov, A.N.) は二十世紀の十大数学 者と言えるでしょうね，と言ったところ，櫃田先生は，「い や，三大数学者の中に入ると言うべきだ」と，即座に言い 返された。もちろん，我々には，その偉大さなどは，とて も理解は出来ない. ただ，そのような偉大な数学者が，た またまそばにいた，数理に強い地質学者（Vistelius, A.B.） が呟いた疑問，「どうして層理面はできるのでしょうね？」 という問題 (Vistelius, 1949) に, 真面目に取り組んで, 一つ の作品（Kolmogorov, 1951）を書いたのであった.

Kolmogorov（1951）が考えたのは，地層の形成には，堆積 作用と一口に言うが，実際には堆積物が運ばれてきて，堆 積する過程と, その後で, 一旦堆積したものが次の段階で, えぐり取られて (wash-out) しまうという過程の積み重な りによってできる，という歴史の結果だ，というモデルで あった. そして，場合によっては，そこにマイナスの厚さ をもった地層が出来る, という考えであった。このモデル では, マイナスの厚さを有する地層を想定することが重要 な点であり，それが実際には，眼に見えず，確認できない こともあって, 彼のモデルについて, 詳しく議論されるこ となく，現在に至っている，以下，述べる拙論では，この モデルを中心に，議論を進める.

\section{最近の研究}

最近は, 多くの堆積地質学者が野外で活躍し, 地層の集 り状態に関する興味が増してきたためか, ここで議論しよ うとする層厚分布についての報告も多くなった。 それらを すべて紹介する能力や時間は，私にはない，ただ，いくつ かの代表的な研究例をまず，簡単に紹介することにする.

まず, 最近の研究例として, フィールドにおける露頭を 観察し，そこで層厚分布について考察した例として，ギリ シャの変動带での研究（Pantopoulos et al., 2013）, 次に, 堆 積層形成の水理実験を試み, 水槽内で形成された DeltaBasinの観察から，層厚分布を議論した例（Straub et al., 2012), そして, 石油探査の観点から, その貯油層の適否に ついて, 層厚分布の視点から, 議論をした我が国の中嶋 （2002）の三例をあげて，紹介する.

Pantopoulos et al.（2013）の報告は，ギリシャの Patras 大 学 Ph.D. の労作を基礎にして解説したもので，ギリシャの 南西部で NW-SE に走る “External Hellenides” 帯に分布する Paleogene turbidite について，連続露頭で層厚を計測した結 果をまとめたものである。そこで検討された露頭は Amfilochia 地区, ならびに, ギリシャ東南端の小さな
Karpathos 島に分布するタービダイトで, 彼らは, 層厚測定 以前に，野外における観察から，例えば，“thickening and coarsening up”と言った堆積環境の特徵を把握している. 重要な点は, この論文では, いわゆるマイナスの層厚を持 つ例を取り上げていないことである。すなわち, 彼らは, Kolmogorovのモデルについては何も述べていない. しか し, 丹念に, 多くの層厚を測定し, その結果を集計してい る. 統計的取扱いの結果から, 測定結果の集計では, それ ぞれの柱状断面について, skewness や kurtosis は計算でき る。そして, それらから, 著者らは,「結果は, “normal (Gausian) distribution”ではない」と結論している. 彼らの 総括（Table 1, p. 45）に示されているように，ある単位の タービダイトについては, まず, “depositional environment” として, “inner fan / channel”とか “outer fan / lobe”といった ように，地質学的に環境を決めている。そして，その環境 におけるそれぞれの層厚分布の平均值, 標準偏差などを計 算している。 この研究は, 実際に露出しているタービダイ トを例にして, その層厚の計測結果を集計した例としては, 極めて注目すべき研究であり，集計結果と堆積環境を比較 するためには実例としては参考にすべき作品である。しか し，これから述べようとするマイナスの厚さを考慮した Kolomogorov のモデルとは関係はない. その点, 次に述べ る Straub et al.（2012）とは全く異なる研究例である.

Straub et al.（2012）には，もちろん，Kolmogorov（1951） や Mizutani and Hattori（1972），Muto（1995）などが引用さ れており, 詳細な検討は, 実際に水槽実験を行って, 流路 を通って運ばれる泥流によって, 如何なる堆積層が形成さ れたかを検討したものであり，異色の研究と言えよう.

ただし，彼らの記載の中には，“Kolmogorov coefficient” という語が各所に出て来る。この語は, 私たちがそう名付 けた語（Mizutani and Hattori, 1972, p. 127-129）であって, そ のことにどうも気づいていないように読める.さらに，も う一点, 彼らは, Kolmogorovがガウスの誤差関数を用いて いると明記しているが，この点，誤解がある，私は，高等 数学についてその公理体系や定理を理解できないので，数 学的に厳密な説明はできない. しかし, Kolmogorov (1949) を見る限り，彼は, “somewhat cumbersome but entirely possible” という表現をはさみながら, Fig. 2 (Kolmogorov, 1949, p. 368）で, "Figure 2 plots $\mathrm{f}(\mathrm{x})$ and $\mathrm{f} *(\mathrm{x})$ for the case" と述べ た後で, $\phi(\mathrm{x})$ にガウスの誤差関数を

$$
\phi(x)=\frac{1}{\sqrt{2 \pi}} e^{-x^{2} / 2}
$$

として示しているだけである，決して，断定しているわけ ではない，想定される層厚分布の形は, 多分, uniformrandom ではなく, normal-ranndom で, しかも単峰性（unimodality）と思われるので, 上記の文章によって, 数学的に 
良く知られている関数の形を一例として示したものと，私 は考える.

Straub et al. (2012) の研究は，この論文の共同研究者のう ち，第二番目に名を連ねているVamsi Ganti が所属する Minesota 大学で実施された。 "Delta Basin facility”と呼ばれ ている装置, すなわち, 大きさ, $5 \mathrm{~m} \times 5 \mathrm{~m}$, 深さ $0.61 \mathrm{~m}$ の水 槽を作り，その一方の角から，水流を流す，それには， $70 \%$ の白い砂と $30 \%$ の黒い砂（実際には無煙炭の粉末）が加え られている. 実験が進むと, この水槽の角から扇状に，デ ル夕状の堆積層ができ上がる，その先端から先は海洋の地 域と想定しておく，何度もこの水流を流して，堆積層が形 成される過程を観察する。水槽の角から， $2.5 \mathrm{~m}$ までのと ころに扇形の堆積層ができあがる，その時，水流の流し口 の先端から $1.75 \mathrm{~m}$ 離れた地点で形成された堆積層の積み 重なりを計測する。これが彼らの実験の概要である。この 種の実験結果を決める多くの因子が知られているので, 実 験の実行にあたっては, 他のいくつかの因子も, 細かく検 討されている. 彼らの研究の目的は, この種の水槽実験に よって, 我々が議論している堆積層の形成過程で，その層 厚分布がいかなる規則性をもっているかを実際に確かめる ことにある，彼らの結論の一つは, Kolmogorov が言うよう な deposition と erosion が起こるとして，それらの頻度を合 わせた現象は, 切断分布（彼らの表現では “truncated Pareto distribution” と記しているが, 私は, 残念ながら, 不勉強で, この語を知らない), とくに, マイナス側の領域まで描いて 考えると，うまく合致するという。

中嶋健（産総研地圈資源環境研究部門）の論文は, Bergen Univ. において行った研究を中心に, 地層の厚さの 分布に関する優れた総括を行っている. 彼の研究の目的 は,

“もし, 坑井から得られる一次元の層厚分布からタービダ イトのサイズまたは体積に関する情報が得られるならター ビダイトの層厚分布は石油探鉱にとって重要な意味を持つ ことになる” (中嶋，2002, p. 316)

と述べているように, 実際に, この種の研究が上記のよう に役立つならば，この分野に扔ける重要な研究課題になる であろう。しかし，彼の卓抜な検討においても，タービダ イトに限らず，一般の堆積岩に関して，この層厚分布の問 題は, 現時点においては，そこまで研究は進んではいない， 中嶋（2002）は，これから述べる Kolmogorov（1951）の研 究をはじめ, Mizutani and Hattori (1972), Drummond (1999), らの研究を読み, それらを検討しながら, 層厚分布につい て, 詳細な総括を行っている. とくに, 層厚分布が如何な る分布（標本分布）をするかについて，確率紙を用いた識 別の実例を示している．彼が示した幾つかの実例とそれに 関する生成環境との関連についての彼の総括, すなわち,
“層厚分布にどの統計則を当てはめるかは恣意性の入る余 地がある”(中嶋，2002，p. 314）

には，私も賛成である，私は，層厚分布の基本的議論が未 熟である過程で, 地質学で議論されている堆積作用や自然 環境に結び付けて議論することはできないと思う. Mizutani and Hattori（1972）が議論したことは，これから詳 しく説明するように, Kolmogorov の考えに基づく堆積作用 のモデルであり，そこに新しく導入されたマイナスの厚さ を持つ地層の存在をどのように, 取り扱うかという点にあ る. 中嶋 (2002, p. 314）も記しているように,

『侵食を受けない場合の元々の地層の層厚確率分布を $\mathrm{f}(\mathrm{x})$ ( $\mathrm{x}$ は層厚) とし, 観察された truncated distribution を $\mathrm{f} *(\mathrm{x})$ とすると, $\mathrm{f}(\mathrm{x})$ と $\mathrm{f}(\mathrm{x})$ との間には次の関係がある（第 2 図参照).

$$
\begin{array}{ll}
\mathrm{f}^{*}(\mathrm{x})=\mathrm{f}(\mathrm{x}) / \mathrm{p} ; & \text { for } \quad \mathrm{x}>0 \\
\mathrm{f}^{*}(\mathrm{x})=0 ; & \text { for } \quad \mathrm{x}<0
\end{array}
$$

ここ係数 $\mathrm{p}$ は地層の保存率を表し,コルモゴロフ係数と呼 ばれる.』

すでに述べたが，このpを“コルモゴロフ倸数（Kolmogorov's coefficent” と名付けたのは, Mizutani and Hattori (1972, p. 129）であって，Kolmogorov 自身がそう呼んでいるわけで はない，私たちが，これらの倸数をそのように呼んで, 読 者に注意を喚起したのは, このモデルに基づいて, 我々が 想定する地質体や堆積層の形成過程を具体化するための手 がかりとしたいと考えたからである.

純粋数学的に議論をした Kolmogorov（1951）はこの係数 $\mathrm{p}$ に対しては, 単に数学的な意味だけを持たせているに過 ぎない，後で話題になる係数 q（Kolmogorov's ratio）に関 しても，全く同様である。

後で, 詳しく述べる予定であるが, 最も本質的な点は上 記の $\mathrm{f}(\mathrm{x})$ をどのように想定するかにある。理想的には，そ れは実際に観察されたデー夕を参考にして，論ずべきもの であるが，現在の状況では，それは出来ない，それには， なお, 幾つかの仮定を扔いて, 議論を進めざるを得ない.

\section{Kolmogorov の地層形成のモデル}

地質学者ではない数学者の Kolmogorov は, 同じ研究所 に居る地質学者であり, 数理に強い関心をもっていた友人 の Vistelius（1949）の議論に対して，まず，次のような地層 形成のモデルを考えた (第 1 図)。この図がこの解説の基 本になるので, 詳しく, 解説することにする.

第 1 図は, Shiriyayev ed. (1986) の中で, Kolmogorovの原 著（1949）（ロシア語）を英文化したものの中で使われてい る図である. 今, その論文を英語で読むと, 彼の考えを理 解するのに役立つ。 


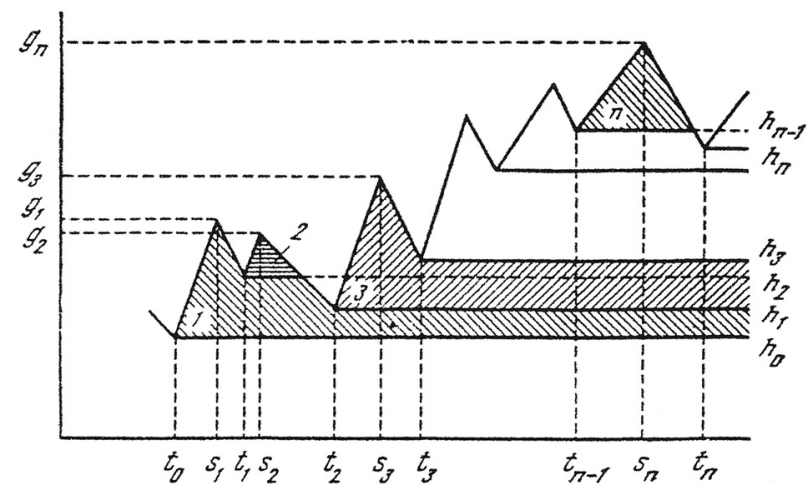

第 1 図地層が形成される過程を, 縦軸に形成され る地層の厚さをとり, 横軸に形成される時間をとっ て示した図.この図は, Shiriyayev ed. (1986) のp. 364 にある図をコピーしたものである.

地層が出来る過程を, このように議論したのは, Barrell （1917）が最初であろう. 彼が記載している地層形成の過 程は，もし，図化すれば, Kolmogorov（1951）のそれとよく 似たものになるであろう. Barrell は, 基礎科学について, かなりの知識があり, 近代的な地質学について具体的に議 論を展開しているが, しかし, 数学者ではなかった。 その ため, 彼は, 自分の概念的な考えを数学的に扱うことはで きなかった。

第 1 図に戻って, 時間の経過と形成される地層の厚さに ついて考えよう。すなわち， $\mathrm{t}_{0}$ から $\mathrm{s}_{1}$ の間に， $\mathrm{g}_{1}$ までの地 層（地層 “1”と名付ける）が出来る. そして, 次の $\mathrm{s}_{1}$ から $\mathrm{t}_{1}$ の間には，地層が削剥される，それに続く $\mathrm{t}_{1}$ から $\mathrm{s}_{2}$ の間 には, $\mathrm{h}_{2}$ から $\mathrm{g}_{2}$ の厚さの地層（地層 “2” と名ずける）が形 成される。しかし, 続く $\mathrm{t}_{2}$ までの間には, 地層は $\mathrm{h}_{1}$ までけ ずられる。 その結果として, $\mathrm{t}_{1}$ から $\mathrm{s}_{2}$ の間に形成された地 層（地層“2”）は無くなってしまう。そして続く $\mathrm{t}_{2}$ から $\mathrm{s}_{3}$ の間に $\mathrm{g}_{3}$ に達するまでの地層（その名前を地層 “3”とす る）が形成される。・・こうして, $\mathrm{t}_{\mathrm{n}-1}$ と $\mathrm{s}_{\mathrm{n}}$ の間に地層 “ $\mathrm{n}$ ” が形成される. しかしその後の削剥のため残っている地層 “n” の厚さは $\mathrm{g}_{\mathrm{n}}-\mathrm{h}_{\mathrm{n}}$ となる.

参考までに, ここで削剥とした語は, 英語では, washout とされている. それは, 現象的に堆積作用の実態を説明し ているのではなく, 強調されているのは，一旦形成された 地層がそこで削られて無くなることを考慮に入れているこ とである，それを何度も繰り返してゆくと，地層の厚さに は, プラスの厚さを持つ地層（例えば，地層“1”）もある が，地層“2”のように，実際にはもう無くなってしまった 地層がある。 それは, つまり, マイナスの厚さをもつ地層 と考えてもよいであろう。

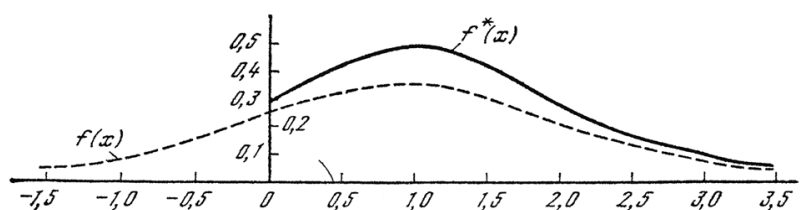

第 2 図地層の厚さを縦軸にとり, 横軸に時間を とって, ある地質体について, その層厚の頻度分布 を表すと, (a)もし, 地層の厚さに関して, プラスの 值だけを考えて図示すると, 実線の曲線 $\mathrm{f}$ * $(\mathrm{x})$ とな り，(b)もし，地層の厚さに関して，マイナスの值も 考慮に入れて図示すると, 点線の曲線 $\mathrm{f}(\mathrm{x})$ のように なる。

以上の点がこの Kolmogorov が考えた地層形成のモデル である，それをさらに十分に理解するために，ここで，普 通一般的に考えられている頻度分布 (distribution) ならび に，切断分布（truncated distribution）との二つを考えること にしょう。それは，第 2 図に示されるように，実線ならび に, 点線によって示される. 数式では, 前者（実線）は $\mathrm{f}^{*}(\mathrm{x})$ と書かれ, 後者 (点線) は, $\mathrm{f}(\mathrm{x})$ と書かれる. 念の ために, $\mathrm{f}^{*}(\mathrm{x})=0$ for $\mathrm{x}<0$ である.

第 2 図は, 第 1 図と同様, Shiriyayev ed.（1986）の中で, Kolmogorov の原著（1949: ロシア語）を英文化した解説の p. 368 に Fig. 2 として揭げられているものをコピーしたも のである.

Kolmogorovの考えは，ここまでである．彼は，f(x)や $\mathrm{f}^{*}(\mathrm{x})$ の形については何も言っていない. 野外の観察をやっ ていない数学者には，それを語る資格はない，それが，お そらくガウスの誤差関数のような形をしているかもしれな いという議論は可能であるが, しかし，そうだと断定はで きない．実際に $\mathrm{f}(\mathrm{x})$ や $\mathrm{f} *(\mathrm{x})$ の形を決めることができる のは, 地層の厚さが，ある地質体で如何なる分布をしてい るかを測って, 集めたデー夕を持っている野外地質の研究 者だけである.

ただし，次の点は，とくに，注意する必要がある。それ は, 実際問題として, 地層厚さの分布が如何なる形をして いるかについては, 誰も知らない. また, その母集団から, 標本抽出を行い, 実測值として, 適切なる小集団を観測値 として得たとしても，それが，『適切』だと言えるような実 例も知られていない. すなわち, 層厚分布論は, 目下のと ころ，まだ，標本抽出論の段階にあるのである。すでに， 述べたように, 中嶋（2002）は, このことを，『層厚分布に どの統計則を当てはめるかは恣意性の入る余地がある』と 表現している.

ここでは, 議論をもっと具体的にして, まず, 服部 勇 


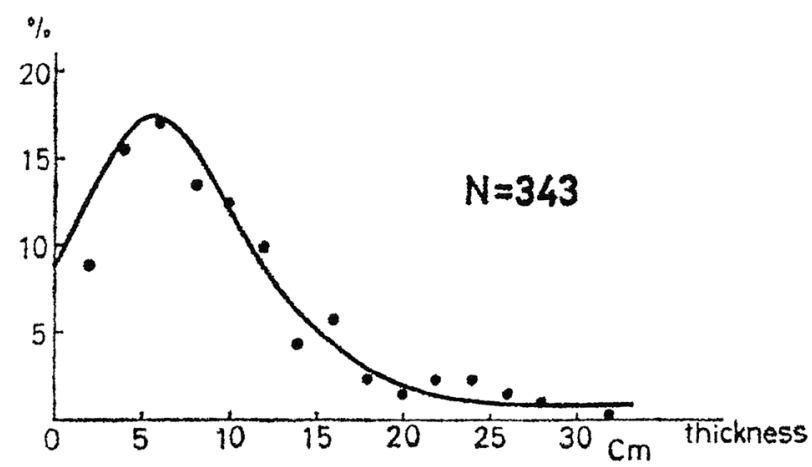

第 3 図掛川層群の地層の厚さの分布を示した結 果. この図は, Mizutani and Hattori (1972) の Fig. 7 at p. 136 をコピーしたものである.

によって集められた掛川層群の地層の厚さの分布 (第 3 図) を例にして議論を進めることにしよう。彼が集めたデータ は，明らかに，切断分布をしているように見える．この分 布（自然が示した層厚分布の実例）を参考にして，以下，議 論を進める.

この図から，これがいわゆるガウスの誤差曲線の一部に 似ていると考える．何に似ているかという想定も，かなり の任意性があるが, 私たちは, $\mathrm{f}(\mathrm{x})$ を誤差関数と考え, そ の, 誤差関数の平均值 $\mu$ とその分散 $\sigma$ を推定した。すなわ ち, 次の二つの值, $\mathrm{p}$ と $\mathrm{q}$ とを計算することができた. 誤差関数の形 :

$$
f(x)=\frac{1}{\sqrt{2 \pi} \sigma} \exp \left(\frac{-(x-\mu)^{2}}{2 \sigma^{2}}\right)
$$

また, $\mathrm{p} と \mathrm{q}$ とは :

$$
\begin{aligned}
& p=\int_{0}^{\infty} f(x) d x \\
& p=\int_{0}^{\infty} x f(x) d x / \int_{-\infty}^{\infty}|x| f(x) d x
\end{aligned}
$$

これらは第 3 図について, $\mu=5.31$ ，および, $\sigma=6.33$, と なり, 次いで, $\mathrm{p}$ と $\mathrm{q}$ は, $\mathrm{p}=0.79, \mathrm{q}=0.80$ となる.

この $\mathrm{p}$ の值は, 試行回数の割合を表している.つまり, p $=0.79$ という值は, 全体で 100 回の堆積作用があった時, 79 回は堆積物が地層として残ったが, 21 回は, 一度, 堆積 した地層が削剥されて無くなってしまったことを示してい る. また, $\mathrm{q}=0.80$ という数值は, 堆積した堆積物の全量の うち， $80 \%$ が地層として残り，20\% は削剥されて，除去さ れてしまったことを示している.

こうして, 数值的に処理した結果は, 或る地域の地質体 の堆積作用について，それがどの程度, “蓄積的”であった か，あるいは，逆に“削剥的”であったかの手がかりにな る.
再度，注意しておくが，上述の $\mu, \sigma, \mathrm{p}, \mathrm{q}$ は，実際の野 外の観察の結果に基づき，さらに，その分布関数がガウス の誤差曲線に似ると仮定して, 計算されたものである点を 忘れてはならない. 考え方の基礎になっているのは, Kolmogorov が示唆した『マイナスの厚さをもつ地層の存 在』にある.

以上の実例に示したように，重要なのは，野外で如何な る地質体について, 如何なるデータが集められているかに よって，それがより蓄積的か，あるいは，削剥的かの議論 ができる，言うまでもなく，具体的な検討には，面倒な計 算をしなければならない。当時, 我々は, 京都大学の大型 電子計算機 Facom 230-60 を使用することができて, その力 を借りて, 計算結果を得た. しかし, それよりも忘れてな らないことは，具体的な野外の測定值があったことであっ た。私自身の例で言えば, 美濃帯の砂岩泥岩互層（つまり， タービダイト）についての測定值があった。 その実測值に 基づいて, いわゆる「地向斜堆積相」あるいは,「変動帯の 堆積相」における特徵を議論することができたのであった.

総まとめとして, Mizutani and Hattori（1972）は, いくつ かの代表的な地質体について, その堆積作用の特徵を, 上 述の指標にしたがって, 区分し，また，特徴づけた。そし て, 実際に経験的に理解されている堆積作用との関係を論 じたのであった。

\section{堆積作用の特徵}

偉大な大数学者 Kolmogorov のモデルは, 我々に, 地層の 厚さを考えるときに, プラスの厚さをもつものとマイナス の厚さをもつものがあることを示唆した。ささらに，それに 基づいて, ある地質体に存在する堆積層（地層群）の層厚 の分布を議論しなおしてみることを教えてくれた.

私は, かつて, 美濃帯に対象を絞って, 研究していたこ ろ, 日本地質学会のほとんどの人が, 石灰岩のある地域に おいて，しかも，紡錘虫の研究だけをしていたことに，大 きな違和感を持っていた，美濃帯には，石灰岩はもちろん 出るが, しかし, 大半は, 砂岩やチャートが分布するとこ ろが多い，それらに手をつけずにいるのは間違っていると 感じていた，そして，そのような地域では，何を研究する かについて考えていた。そして，まだ，何も知らない頃か ら, ただただ, そこに産出している砂岩泥岩互層（夕ービ ダイト, 当時はまだこの言葉もなかった）の厚さを測って いたそその結果を Mizutani and Hattori（1972）に紹介し，検 討の対象とした.

その研究は，層厚を丹念に測定しておけば，計算によっ て, その堆積学的特徵を, このモデルに基づいて, 検討で きることを示した実例であった，私たちは，その実例を， 


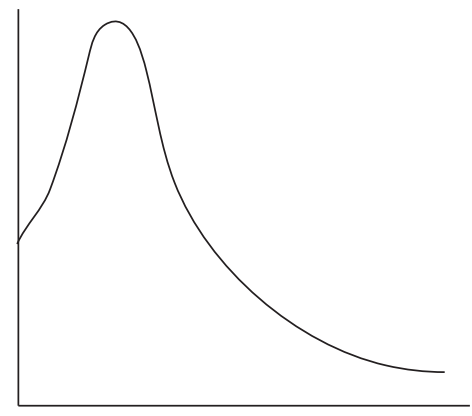

第 4 図 層厚分布から，かなり「蓄積的」と想定でき る頻度分布曲線の例.

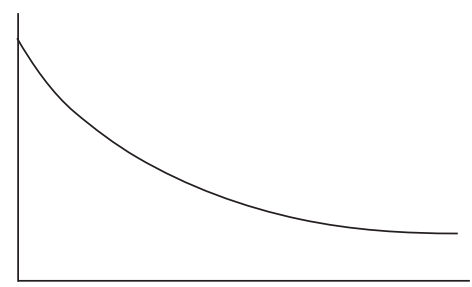

第 5 図層厚分布から, かなり「削剥的」と想定され る頻度分布曲線の例.

自分たちのデータばかりでなく，他のタービダイト・氷縞 粘土などさまざまな堆積物について Atkinson（1962）, Bouma (1962), Potter and Siever (1955), Kelling (1969) 等 のデータを整理し，総括しておいた（Mizutani and Hattori, 1972, Table 4 at p. 138-140)。これらを相互に比較してみる と, 助上に載せた堆積物の特徵を, “alluvial or fluvial deposits", "near-shore sediments”, “geosynclinal sediments” およ び，“varves”に大きく区分できると思われた.

私は, これらの結果, さらに, その後に書いた論文（水 谷, 2000）などで, 何度も, 議論しているうちに, いわゆる 「層厚解析」についての概略の把握ができると, 感ずるよう になった。

例えて言うと, 慣れてしまえば, 肉眼で眺めただけで, 砂岩が graywackeであるか, それとも, 別の夕イプの砂岩 であるかは，分かるようなものだと思う.

すなわち，地層を（たった数枚では，駄目だが）眺めたと き，その厚さがほとんど一定で，しかも，多数が集まって いる場合には, それはおそらく, 切断分布によって示すと, 厚さ $=0$ の縦軸から右によったところに大きな極大值をも つようなものだと理解できるであろう.すなわち, それは, 非常に「蓄積的」な堆積作用であったと考えられるのであ る(第 4 図).

逆に，もし，かなり横にひろがり，また，頻度が低い分布

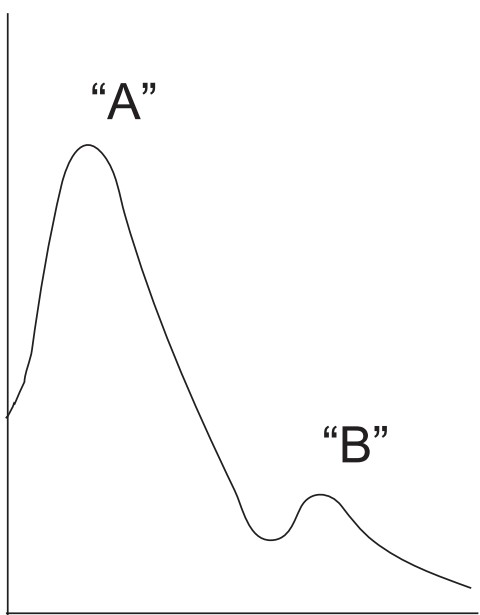

第 6 図岡山県蒜山原層の層厚分布曲線（この図は, 想定されたものである).

を示す場合 (第 5 図), マイナスの厚さも考慮に入れると, 厚さがマイナスの領域にもかなり広くひろがるような，換 言すれは，かなり「削剥的」な堆積環境であったと考えら れることがわかる。

上述の例のように, 層厚分布曲線を頭に描くことができ, さらに，それから，その地質体が他と比べて，より「蓄積 的」であったか, あるいは，より「削剥的」であったかを判 断し，区別することができるようになったら，野外調査も， さらに面白くなるであろう。

私は, 今回, 「堆積学研究」の最新号に揭げられた岡山県 の蒜山の湖成層の露頭写真を見て，私は，この蒜山原層の “地層群” は, 薄い色の薄層からなる部分と, 濃い色のやや 厚い層からなる部分の 2 種類の “地層群”からなると直観 的に分けられると見た。

この写真だけから判断しても, 今, 層厚分布を描けば, その層厚頻度分布曲線は, 第 6 図のように, 双峰性 (bimodality）がある。そのうち, 向かって左にある頻度の高い 山は薄い色で薄層からなる “地層群”（地層群 “A”と名付 ける）と向かって右にあるやや頻度の低い山の，すなわち， 濃い色で厚い層からなる “地層群”（地層群 “ $\mathrm{B} ”$ と名付け る）からなる.

これまで，述べてきたように，この図から，我々は，2 種 類の異なった堆積環境における堆積作用があったと推定す ることができるであろう。その時, 第 6 図から, さらに, それぞれについて, 切断分布曲線を描いて, 地層群 “A” 地層群 “B” の特徵を, すでに述べた Kolmogorovのモデル を使って，堆積環境を推定することが出来るであろう。私 達はすでに経験によって, 地層群 “A” は湖成層の特徵をも つものと考えられる。しかし，今のところ，地層群“B”が 


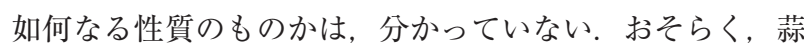
山原層は, これら二つの地層群からなるというのが特徵な のであろう。しかし, 一方では, このうちの片方, 層群 “B” が他の地域の異なった環境の堆積作用を特徵づけるものと 判明したら, 結論的に蒜山原層の堆積環境をさらに具体的 に想定することができる，その時，我々は，この問題は， もう数学者の手を離れたものと考えてよいであろう。そし て, そこは, 我々が最も得意な「堆積環境の変化」の知識を 基に, 議論と推論を戦わせることになるであろう。 そこに は新しい問題があり, 期待も大きい.

\section{おわりに}

私たちの仕事 (Mizutani and Hattori, 1972) は，その原稿を 投稿した段階で, 編集責任者は, 原稿を, 念のために, Kolmogorovに送って, 彼の感想を訊ねている. その結果 を, Visteliusは, 個人的に, 私に知らせてくれた. それによ ると, Kolmogorovはとても忙しくて，われわれの原稿を細 かく検討する時間はないが, 扔扔よそ, この内容で問題は なかろう, というものであった，私は，その結果を知って， とても嬉しく感じた．とにかく, 何とか, Kolmogorov(1951) を読んで, 理解できたことに大きな満足を感じたのであっ た。

我々の仕事については，次のような最近の情報がある. 大数学者 Kolmogorovの業績については, 世界中から, 注目 が集まっている，そのため, 彼の弟子（抢そらく, 愛弟子) である Shiriyayev, A.N. が編者になって, いわゆる Collected Papers（Shiriyayev, 1986）が編纂された。 そして, そ れが, 英訳されて出版されている. その中に, もち万ん, 彼らの先生, Kolmogorovが書いた原著が揭載されている. また，その彼の書いた論文に関して，世界から如何なる反 応があったかも, 紹介されている. とくに, 地質学に関す る問題については, 彼らソ連の数理地質学者の仲間である Vistelius（1986）が解説を書いている. そして, 上記の層厚 分布の議論に関して, 私たちの論文 (Mizutani and Hattori, 1972）を紹介している.

私は, Vistelius と個人的に会ったことがある. 当時, 信 州大学の黒田吉益先生 (当時: 学術会議会員) に招かれて, 訪日した時, 名古屋へ行きたいと彼が語ったからであった. 私は, 彼を彼の希望のところ (花崗岩地带) 一案内した. また, 当然, 数理地質学についても, 議論した. 彼は, Chicago から出ていた Journal of Geology の編集委員の一人 として, 数理地質学部門の編集業務に当たっていた。だ ら, 当時, 流行を始めていたこの分野の研究者たちには詳 しく, 彼らについて人物月旦をやってくれた。 それは, と ても良い勉強になった。
帰途，お土産にと，彼の同僚と子どもとに，赤のボール ペンと色鉛筆が欲しいというので, 丸善へ連れていったら, 彼は, 何と, それぞれ 1 本か 2 本を選んで買うという。あ まりの貧しさに私は驚いた。私は, 彼の目の前にあった ボールペンを一つ掴み (十数本) と色鉛筆の 24 色の 1 七ッ 卜と買って, 私が支払って, 彼に与えた。私は, ソ連とい う国が実際には，かなり，貧しいことを実感として知った。 しかしながら, そのような環境においても, 世界一流の数 学者が野外調查をやっている地質学者と共同研究をしてい るというその学術的な研究環境に, 舌を巻いて驚いたので あった。 そして, 彼らがアメリカと競争して, 宇宙開発に 乗り出していったその実力を推し量ることもできたような 気がした。

謝辞 : この報告に関係した研究には, 多くの人にお世話に なった。まず, 私が大学院修士課程へ進み, 独りで Kolmogorov（1951）の論文を読んだ時, 大学の同級生で, 数学 科へ進んだ当時の名古屋市立大学梅田助教授には, 私の最 初の草稿を読んでいただいて，いろいろ有益な助言をいた だいた。

その後, 数学科の櫃田倍之先生には, Prof. Kolmogorov と の交流について生々しい体験を伺い, とても啓発された。 櫃田先生は, Prof. Kolmogorov のゼミに参加されていて, そ のことについても話を聴いた.

さらに, 共同研究者として, 一緒に, Kolmogorovの論文 を再読し, 自分たちの論文を書いた服部 勇（福井大学名 誉教授）には, 今回のこの草稿に関しても, いくつかの助 言をいただいた，服部 勇氏は，数学的な厳密さを尊び, その視点から, 私の雑な考えに対して, 鋭い批判を与えて くれた。しかし, 私自身は, 数学者の立場と地質学者の立 場を, 峻別して, 議論すべきであるとの視点に立ってこの 草稿をまとめた. 本来, これは, 私と彼との連名で書き上 げるべき作品であるが, 彼の希望も考えて, 私の単名で書 かせていただいた，もちろん，内容についての全責任は, 私にある。

私達の作品を, Vistelius, A.B. は, Prof. Kolmogorovに紹 介し, その仲介の労をとってくれた. さらに, 彼は, 後に なって，日本にやってきて私と一緒にフィールドへも出か けた。 そして, 1953 年 4 月 6 日, 名古屋大学地球科学教室 で特別講演をしてくれた。 もちろん, Vistelius, A.B.にはそ の後も, お世話になっている.

彼が来日したとき, 学術会議会員として, 彼の世話をさ れた信州大学の黒田吉益教授にも, 私は, 感謝している. その頃, 黒田吉益教授は, 数理地質学に強い関心をもって 抢られ, とくに, マルコフ過程モデルの地質学, とくに, 岩 石学への応用について, 検討されていた. 
さらに, その後, 私が名古屋大学を定年退官し, 日本福 祉大学情報社会科学部へ移ったころにまとめた報告 (水谷, 2000）については, 岡田博有先生に草稿を読んでいただい た.

なお，本論の手稿を丁寧に読んでいただき，投稿につい て適切なる助言をいただいた信州大学理学部の保柳康一先 生, ならびに, 覆面查読者の某氏には, あらためて, 心から 感謝する，彼らの助言によって，私の筆がいかに軽くなっ たか，その有りがたさを表す言葉がない，彼らの存在は， この学会にとっては, 実に貴重だと痛感した.

以上，列記したように，私の考えは，これら国内外の研 究者の多くの方々に議論をしていただいた。これらの人々 には, いつも, 深い感謝の気持ちをもっている. 最後に, これらの方々の名をここに記し，謝辞とする.

\section{文献}

Atkinson, D.J., 1962, Tectonic control of sedimentation and the interpretation of sediment alternation in the Tertiary of Prince Charles Foreland, Spitzbergen. Geol. Soc. America, Bull., 73 (3) 343-364.

Barrell, J., 1917, Rhythms and the measurements of geologic time. Bull. Geol. Soc. Am., 28, 745-904.

Bokman, J., 1957, Suggested use of bed-thickness measurements in stratigraphic descriptions. Jour. Sediment. Petrol., 57, 333-335.

Bouma, A.H., 1962, Sedimentoloty of some flysch deposits; a graphic approach to facies interpretations, Elsevier Publ. Co., Amsterdam, $168 \mathrm{pp}$.

Ishihara, Y. and Sasaki, H., 2015, Lacustrine varved diatomite and deformation stuructures in the Middle Pleistocne Hiruzenbara Formation, Jour. Sediment. Soc. Japan, 74 (2), 112.

Drummond, C.N., 1999, Bed-thickness structure of multisourced ramp turbidite: Devonian Brallier Formation, central Appalachihan basin. Jour. Sediment. Res., 69, 115-121.

Kelling, G., 1969, The environmental significance of cross stratification parameters in an Upper Carboniferous fluvial basin. Jour. Sediment. Petrol., 39 (3), 857-875.

Kolmogorov, A.N., 1949, Solution of a probabilistic problem relating to the mechanism of bed formation. Siriyayev. ed. 1986. pp. 364368. (the Russian paper was published in Dokl. Akad. Nauk, SSSR, 65 (6), 1949, 793-796)

Kolmogorov, A.N., 1951, Solution of a problem in probability theory connected with the problem of the mechanism of stratification.
Am. Math. Soc. Trans., no. 53, 171-177.

Mizutani, S. and Hattori, I., 1972, Stochastic analysis of bed-thickness distribution of sediments. Mathematical Geology, 4 (2), 123-146. 水谷伸治郎, 2000, 確率過程モデルに基づく堆積環境の解析につ いて, 日本福祉大学情報社会科学論集, 3, 1-20.

水谷伸治郎, 服部 勇, 1973, タービダイトおよびそれに関連す る砂泥互層の層厚解析, 海洋科学, 5, 23-28,

Muto, T., 1995, The Kolmogorov model of bed-thickness distribution: An assessment based on numerical simulation and field-data analysis. Terra Nova, 7, 417-423.

中嶋 健, 2002, タービダイト層厚分布の統計学的解析, 一その 貯留岩キャラクタリゼーションへの応用の可能性一. 石油 技術協会誌, 67 (3), 308-320.

Pantopoulos, G., Vakalas, I., Maravelis, A. and Zelilidis, A., 2013, Statistical analysis of turbidite bed thickness patterns from the Alpine fold and thrust belt of western and southwestern Greece. Sedimentary Geology, 294, 37-57.

Pettijohn, F.J., 1943, Archean sedimentation. Bull. Geol. Soc. Am., 54, 925-972.

Pettijohn, F.J., 1949, Sedimentary Rocks, Harper \& Brothers, N.Y. 526 pp.

Potter, P.E. and Siever, R., 1955, A comparative study of Upper Chester and Lower Pennsylvanian stratigraphic variability. Jour. Geol., 63 (5), 429-451.

Shiryayev, A.N., ed. 1986, Selected Works of A.N.Kolmogorov. Vol. II: Probability Theory and Mathematical Statistics. Kluwer Academic Publishers, Mathematics and Its Applications (Soviet Series), Vol. 26, Kluwer Academic Publishers, Norwell, MA, USA. 597 pp.

Simonen, A., 1953, Stratigraphy and sedimentation of the Svecofennidic, early Archaen supracrustal rocks in southwestern Finland. Bull. Comm. geol. Finlande, no. 160, 1-64.

Simonen, A. and Kouvo, O. 1951, Archean varved schists north of Tampere in Finland. Bull. Comm. geol. Finlande, no. 154, 93-114. Straub, K.M., Ganti, V., Paola, C. and Foufoula-Georgiou, E., 2012, Prevalence of exponential bed thickness distributions in the stratigraphic record: Experiments and theory. Journal of Geophysical Research, 117, 2011-2029.

Vistelius, A.B., 1949, On the question of the mechanism of the formation of strata. Doklady Akadmy Nauk CCCP, vol. 65, 191-194.

Vistelius, A.B., 1986, On inter-bed washout (no. 37) in Shiriyayev, A.N. ed. 1986, Selected Works of A.N. Komogorov, Vol. II: Probability Theory and Mathematical Statistics, Kluwer, Academic Publishers, pp. 591-597. 